\title{
最近の歯学
}

\section{2. 摄食機能評価}

\author{
義歯安定剤（義歯粘着剤）の使用が全部床義歯装着者の咀嚼機能に与える影響 \\ 東京医科歯科大学大学院医歯学総合研究科 口腔機能再構築学系 捸食機能回復学講座 捸食機能評価学分野 \\ 藤森拓人，平野滋三，早川 嚴
}

現在，さまざまな種類の義歯安定剂が多くのメーカーから 市販されており，年間売上総額は 100 億円に達しようとして いる。義歯安定剤は成分, 効用の点から大別すると, 粘着性 の高い物質を主成分とした義歯粘着剤と，クッションのある ゴム状の物質を主成分としたホームリライナーの 2 種類に分 けられる。このうち, ホームリライナーは流れが悪く, 額堤 に対する義歯の位置を変えてしまうため, 顎間関係に狂いが 生じ，その結果歯槽骨に著しい吸収を生じやすい。一方，義 歯粘着剤は流れが良く, 義歯床粘膜面に薄く均一に広がるた め, 顎間関係に狂いが生じにくく, 適切に使用すると, 食片 圧入を防ぎ機械的刺激を減弱する, 義歯の維持安定の向上に 有効であるなどの肯定的な報告がみられる。これらの理由か らホームリライナーは使用すべきではなく，使用の必要があ る場合は義歯粘着剂に限られるべきであると考えられる。し かし, 義歯粘着剤について, その使用効果について調べた研 究は数少ない。さらに適応症についてもこれまでのところ明 らかにされていない。高度に靧堤が吸収すると, 咀嚼時に義 歯が容易に移動し疼痛を生じやすい。このような症例では, 特に義歯粘着剂の粘着性が咀嚼機能の改善に有効に作用する と思われるが，不明である。

そこで当教室では，義茵粘着剤の使用が咀嚼機能に及ぼす 影響を評価し，さらに顎堤の状態による義歯粘着剤の使用効 果の違いについて検討した ${ }^{1)} 。$

東京医科歯科大学歯学部附属病院で製作され, 諸調整が終 了して 6 力月以上経過した適合状態が良好な上下顎全部床義 歯を装着した 16 名の無歯顎者が実験に参加した。Kapur の 方法 ${ }^{2)}$ 参考に, 被験者を顎堤状態の良好なグループ (G group) 8 名と, 顎堤状態が不良なグループ (P group) 8 名 の 2 グループに分類した。最大咬合力, 篩分法による咀嚼能 力の測定，および咬筋筋活動の記録を義歯粘着剂使用時と不 使用時について行った。咬筋筋活動の記録より筋放電持続時 間と咀緭周期, およびそれらの変動係数を算出した。得られ た測定值を，顎堤の状態と義歯粘着剤の使用の有無を因子と した反復測定 2 配置分散分析と, 対応のある $t$ 検定を用いて 統計解析を行い, 義歯粘着剤の使用効果を評価した。その結 果, 両グループともに, 義歯粘着剤の使用により最大咬合力 は有意に増加し, 咀嚼時の咀嚼リズムは有意に安定した。ま
た顎堤状態が不良なグループのみ，義歯粘着剤の使用により 咀嚼能力は有意に向上し, 筋放電持続時間は有意に減少した (表 $1 ， 2$ )。

本研究結果より，義歯粘着剤の使用は顎堤の状態にかかわ らず，最大咬合力の増加と咀嚼リズムを安定させる効果があ ることが示唆された。また簤堤状態が良好な場合は, 咀嚼能 力の向上に義歯粘着剤の使用があまり効果がない可能性も示 唆された。しかし一方で義歯粘着剤の使用による咬合力の増 加は, 顎堤に過度な負担を与え, 顎堤の吸収を促進する可能 性も考えられる。そのため今後は, 義歯粘着剤を長期使用し た場合の顎堤に対する影響についても検討していきたいと考 えている。

\section{文献}

1) Fujimori, T., Hirano, S. and Hayakawa, I. : Effects of a denture adhesive on masticatory functions for complete denture wearers-consideration for the condition of denture-bearing tissues-. J. Med. Dent. Sci. 49: 151-156, 2002.

2) Kapur, K. K. : A clinical evaluation of denture adhesives. J. Prosthet. Dent. 18:550-558, 1967.

表 1 義歯粘着剂不使用時と使用時における最大咬合力と咀噮能力

\begin{tabular}{|c|c|c|c|c|c|}
\hline & \multicolumn{2}{|c|}{ 最大咬合力 $(\mathrm{N})$} & \multicolumn{2}{|c|}{ 咀嚼値（\%） } \\
\hline & & 平均 & 標準偏差 & 平均 & 標準偏差 \\
\hline \multirow{3}{*}{$\mathrm{G}$ group } & 義歯粘着剂不使用時 & 112 & 54.2 & 45.5 & 15.3 \\
\hline & 義歯粘着剤使用時 & 123 & 65.8 & 44.7 & 13.8 \\
\hline & $P$ 値 & \multicolumn{2}{|c|}{$0.02^{*}$} & \multicolumn{2}{|c|}{0.75} \\
\hline \multirow{3}{*}{ P group } & 義歯粘着剂不使用時 & 54.9 & 20.1 & 22.6 & 3.92 \\
\hline & 義歯粘着凧使用時 & 81.1 & 25.6 & 31.7 & 8.95 \\
\hline & $P$ 值 & \multicolumn{2}{|c|}{$0.02^{*}$} & \multicolumn{2}{|c|}{$0.02^{*}$} \\
\hline
\end{tabular}

${ }^{*}$ : 有意水準 0.05 で有意差あり

表 2 義歯粘着剂不使用時と使用時における筋放電持続時間, 咀畄周期およびそれらの変動係数

\begin{tabular}{|c|c|c|c|c|c|c|c|c|c|}
\hline & \multicolumn{2}{|c|}{ 筋放電持続時間（ms） } & \multicolumn{2}{|c|}{ 咀嚼周期（ms） } & \multicolumn{2}{|c|}{ 筋放電持続時間の変動係数 } & \multicolumn{2}{|c|}{ 咀嚼周期の変動係数 } \\
\hline & & 平均 & 標準偏差 & 平均 & 標準偏差 & 平均 & 標準偏差 & 平均 & 標準偏差 \\
\hline \multirow{3}{*}{ G group } & 義歯粘着剤不使用時 & 257 & 53.4 & 640 & 108 & 0.16 & 0.05 & 0.12 & 0.03 \\
\hline & 義歯粘着㶡使用時 & 255 & 73.4 & 687 & 177 & 0.14 & 0.04 & 0.11 & 0.04 \\
\hline & $P$ 值 & \multicolumn{2}{|c|}{0.99} & \multicolumn{2}{|r|}{0.14} & \multicolumn{2}{|c|}{$0.003^{*}$} & \multicolumn{2}{|c|}{$0.04^{*}$} \\
\hline \multirow{3}{*}{$\mathrm{P}$ group } & 義歯粘着剂不使用時 & 309 & 62.4 & 613 & 92.1 & 0.18 & 0.02 & 0.14 & 0.01 \\
\hline & 義歯粘着剤使用時 & 258 & 35.7 & 625 & 81.6 & 0.14 & 0.01 & 0.11 & 0.02 \\
\hline & $P$ 値 & \multicolumn{2}{|c|}{$<0.001^{*}$} & \multicolumn{2}{|c|}{0.14} & \multicolumn{2}{|c|}{$0.003^{*}$} & \multicolumn{2}{|c|}{$0.04^{*}$} \\
\hline
\end{tabular}

* : 有意水準 0.05 で有意差あり 